Article

\title{
Developing Transversal Competencies in the Sociodramatic Space: Narrative of a Curricular Experience in Higher Education
}

\author{
Sofia Veiga
}

check for

updates

Citation: Veiga, S. Developing

Transversal Competencies in the Sociodramatic Space: Narrative of a Curricular Experience in Higher Education. Educ. Sci. 2022, 12, 125. https://doi.org/10.3390/ educsci12020125

Academic Editors: Miguel A. Santos Rego, Sofia Castanheira Pais and Concepción Naval

Received: 6 December 2021

Accepted: 30 January 2022

Published: 14 February 2022

Publisher's Note: MDPI stays neutral with regard to jurisdictional claims in published maps and institutional affiliations.

Copyright: (C) 2022 by the author. Licensee MDPI, Basel, Switzerland. This article is an open access article distributed under the terms and conditions of the Creative Commons Attribution (CC BY) license (https:// creativecommons.org/licenses/by/ $4.0 /)$.
Centre for Research and Innovation in Education, School of Education of the Porto Polytechnic Institute, 4200-465 Porto, Portugal; sofiaveiga@ese.ipp.pt

\begin{abstract}
Higher Education plays a decisive role in the training of competent professionals and active, responsible and critical-thinking citizens. In addition to acquiring rigorous technical-scientific knowledge specific to their degree, students are also expected to develop a range of transversal skills essential for a successful academic and professional career. This article aims to narrate an experience of obtaining a Social Education degree. Since its origins, it has been assumed that students in this field should: (a) acquire specific technical-scientific knowledge; (b) get to know themselves as individuals; and (c) develop a set of transversal skills essential to relationships, some of the most salient being active listening, empathic capacity, acceptance and respect for others, trust, curiosity, creativity, confidentiality and a reflective attitude. It thus aggregates a set of Curricular Units whose main purpose is the personal, social and professional development of students, formed within active methodologies. Sociodrama is one such methodology of teaching and learning in the context of two Curricular Units of this degree, and this article focuses on my experience lived within the scope of these units.
\end{abstract}

Keywords: transversal competencies; sociodrama; higher education

\section{Introduction}

In recent decades, European Higher Education has undergone relevant changes, resulting from a period of intense massification, based on the adherence to the principles of the Bologna Declaration [1-3] and from the demands of a competitive and constantly changing labor market.

Everyday life, characterized by unpredictability, instability and mutability, has demanded a rethink of the training on offer, which is the curricula, the teaching-learning and assessment methodologies, and professor and student roles and relationships. As far as these aspects are concerned, the last two years have been especially challenging. The confrontation with an unexpected pandemic situation required Higher Education Institutions to analyze and recreate themselves in order to train competent professionals who will also be responsible and proactive citizens committed to societal challenges.

In this context, it is no longer conceivable to maintain a traditional teaching model, limited to a technical and scientific approach, nor to maintain the implementation of teaching in terms of learning methodologies marked by an expositive logic that promotes a passive and non-autonomous attitude among students and distances them from professors. An expositive method, as referred to by Almeida and Vasconcelos [1] and Rosário et al. [4], is usually accompanied by the use of superficial learning approaches and of a seasonal study based on memorization techniques, focusing on the final evaluation, to the detriment of a more continuous, significant and profound learning. This logic contradicts several studies [5,6] which argue that students' learning is determined mainly by what they are, know and do, rather than by what a professor teaches. The latter acts as a facilitator of the whole learning process [7]. 
Despite the fact that the acquisition and comprehension of specific technical and scientific knowledge is fundamental for the construction of a professional identity and praxis, this knowledge in itself seems insufficient to respond to the demands of a challenging, competitive and rapidly changing labor market and, simultaneously, of the role of citizen that is expected to be active and intervening.

Within this framework, it is essential that students-future professionals-acquire and develop a set of competencies, generic or transversal, that allow them to respond in active, positive, spontaneous and creative ways to the multiple challenges that they will face throughout their life paths. This would apply to their personal, social, academic and/or professional domains, assuming their learning has engendered them with a critical awareness of their abilities, potential and resources as well as their limits and limitations [8-10]. In the professional domain, for example, students must equip themselves with skills that facilitate the process of transition to the labor market and exercise their professional activity, which may encompass diversified functions in different contexts and with interlocutors who vary in characteristics and levels of demand [11].

There is a large number of multiple soft skills to be developed, such as communication skills, organization and time management, teamwork and leadership skills. By definition, soft skills are relevant for everyone, in different contexts, and remain important over time [11]. As Jardim et al. [10] state, they "play an important role in young adults' personal, social, and professional development, and may come to be determinant in their future employability and professional performance" (p. 3).

The development of a set of soft skills requires more open and flexible curricula, with links to practice and life experience, and more active and innovative teachinglearning methodologies.

The benefits and inevitability of using more traditional methodologies, which are essentially expositive, in specific moments are not to be underestimated. Nonetheless, it seems essential for meaningful teaching that is sensitive to students' needs in their training and development, to have the option of more active methods. These should be based on the student, and be centered on the student's acquisition of technical-scientific knowledge as well as transversal competencies. Such optional methods should also take into account the demands and the specific knowledge of the course, the realities (formative, cultural, linguistic, social) of each student, the requirements of their professional role, and the labor market.

The training priorities should be, as set forth in the Bologna Declaration, students, their work and their learning process. Furthermore, with the massification we are witnessing in Higher Education, learners have more heterogeneous motivations and different expectations, competences and objectives. Thus, there is an importance in: (a) curricula being sufficiently open to the needs and particularities of students; (b) teaching and learning methodologies being active, creative and innovative; (c) stimulating interpersonal relationships and cooperation between individuals; (d) multidisciplinary approaches; and (e) continuous assessment models. All these aspects enable students to become authors and actors committed to meaningful and profound learning process $[1,4]$.

In this scenario, professors and teaching are no longer the focus [12]. This shift requires a reconfiguration of the entire educational situation. As Tsankov [13] states, "This requires: (1) redefining the goals of education; (2) paying special attention to students' needs and learning motives; (3) introducing adaptive teaching strategies; (4) designing a dynamic environment which supports learning-flexible, mobile, guaranteeing interaction and cooperation; (5) reaching a new level of monitoring and evaluating learning outcomes" (p. 134).

Thus, it can be seen that Higher Education institutions, especially after the implementation of the Bologna process, have been committed to the intentional promotion of the development of transversal or generic competencies in students [11], since various experiences and studies $[14,15]$ have shown that these contribute, to a large extent, to the 
students' competence and academic and professional success, and to their affirmation as persons and active citizens in the reality(s) where they move.

If this premise is valid for higher education students in general, it is even more so for relationship professionals, as is the case with social workers and educators. As professionals of proximity, relation and help, they work hand in hand with individuals in order to change their realities, via a path of autonomy, learning and democratic and collective participation. Thus, they should have training that develops their "know-knowing" (knowledge), "knowdoing" (skills), "know-being" (attitudes, social skills) $[16,17]$ and "know-transforming oneself" (openness to change) [17].

\section{Sociodrama in the Training of Social Educators}

The Social Education degree of the Higher Education School of Porto Polytechnic Institute is aware of the working requirements of social educators. Therefore, it seeks to provide a technical and scientific training, but also develop a range of transversal skills essential for a successful academic and professional career. It thus aggregates a set of Curricular Units, whose main purpose is the personal, social and professional development of students, developed within teaching-learning methodologies that rely on the active participation of students to construct knowledge, on their development of critical attitudes and on their building up of a professional, interventionist and reflexive attitude. Sociodrama is used as a methodology of teaching and learning in the context of two Curricular Units: one in the second year of this degree (40 teaching hours) and an-other in the third year (35 teaching hours).

The option for Sociodrama derives from the fact that the intervention is developed with natural groups and is focused on the discovery and development of common roles and avoids a more private and psychodramatic exploration, which may overexpose students $[18,19]$. As referred to by Wittinger [20], there are varied definitions of Socio-drama. Sharing the vision of Álvarez Valcarce [21], one considers that Sociodrama con-sists of a therapy of natural groups and is based on the assumption that the members: (a) share a set of cultural and social roles; (b) live a common history; and (c) experience a set of relationships, conflicts, issues and problems that are specific to them. Despite its focus on collective issues, it still takes into consideration the individuals.

As the classes are of a practical nature, the groups are small. So, each curricular year usually has five or six classes. They are composed of 15 to 25 students who are mainly: female, Caucasian, aged between 19 and 22, and single. For most of them, the Social Education degree was their first option.

Based on the connection between mind and body, a sociodramatic session comprises three phases: warm-up, action and comments; five instruments: protagonist, stage, auxiliary-ego, director and audience; and three contexts: social, group and dramatic. Action is played creatively according to a set of techniques that can and should be mobilized at specific moments and circumstances, among which one highlights: role reversal, sculpture, soliloquy, double, role-play, dramatic games and sociometry [22-24].

The sessions are held weekly in broad and adapted classrooms, in order to be a setting as close as possible to that proposed by Moreno [22]. The presence of an imaginary stage predisposes students to action and the semi-circle arrangement activates in them the "Audience Instinct" [25]. Such sessions are usually not prepared, but that possibility may also be used at certain times and circumstances. In any case, these sessions are based on the spontaneity of the protagonist and on the objectives of the training and may be shaped by empathy, by opening to new and unexplored worlds and by the creativity of the director. The director is a professor (the author of the article is one of the professor-directors in charge of these Curricular Units), trained in the psychodrama model and with substantial knowledge of institutional dynamics and of the principles and mode of operation of the degree. Although the director is primarily responsible for the entire Sociodrama process, particularly for the warming-up of the group, unlocking embarrassing situations or inhibitors of group work and contextualizing or clarifying the scientific and technical 
issues discussed, he/she is continuously assisted by the auxiliary ego (the auxiliary egos are equally psychodramatists or alumni who have experienced this method for two years. For the advantages of the auxiliary ego being played by alumni, cf. article [26]) and by the elements of the group.

In the warm-up phase, after assessing the state of the group and understanding which one is emergent, the director chooses the protagonist and/or theme and focuses on it during the necessary warm-up for emotional dramatic work. In this context, the theme acquires particular relevance, and the work is then mainly centered on its exploration. This stage is particularly important, because its quality and duration influence the fluidity for the next stages. The warm-up phase is the most complex and difficult, and in which the greatest resistance is observed, namely because it is the phase when silence is most notorious. Since the material to work on comes from students, it is expected that they reveal themselves and expose the issues, problems and/or themes of their preference. However, it has been shown that exposing themselves is not (so) easy, and the freedom and autonomy allowed by this methodology, although desirable, are also feared. Students are required to get involved and to show a responsibility to which they are little used to. Therefore, it is notorious that the desire they express, particularly during the initial contact with such a methodology, is that the director acts more as a guide, bringing specific issues to discussion. Although this guidance can be done in certain moments of a session, the director does not seek to provide much objective guidance so that groups can also find their own way, evolve by themselves and are not always stuck to a dependency relationship. The director encourages students to verbalize their feelings, fears and desires, trying to meet, in every moment, their real needs, gradually warming them up to work on such needs. During this work there are particularly important elements identified as boosters of groups. They show a natural tendency to approach and manage the resistance of other elements, revealing themselves as natural allies of the director, bringing up issues for discussion and feeding the dialogues that may have started.

During the action or dramatization phase, the protagonist is invited to go on stage. Because the methodology is based on Sociodrama, the protagonist is the group itself. In certain situations, an individual or a small group may be chosen to experience this role. The type of proposed scenes and the selected techniques, while revealing the therapeutic hypotheses and the director's intervention, are determined by the objectives of the intervention, by the protagonist and by the group development stage.

One advantage of the Sociodrama model over other group approaches in the training of students in Social Education is its emphasis on drama, action and relations. Unlike what happens in a group context, in which utterances are limited to a circumscribed group of students, in a drama context words and deeds are spontaneously used by most or all of the students. However, the type of scenes created may condition personal exposure and interpersonal interaction. When scenes involve any type of action, with or without discussion, there is a greater involvement and collaboration of most students. In these situations, information and personal positions circulate naturally, enabling a spontaneous flow of communication and negotiation: students present their own views, opinions and thoughts and listen to others, they investigate new ways of reading, (re)consider pathways, evaluate alternatives, make choices and organize resources, among other things. Even the elements that avoid self-exposure, take on a much more active and intervening attitude in this type of exercise.

During the comments phase, students are encouraged to provide feedback about what they saw and felt during the session, highlighting how they lived the drama, and also to accept, with tolerance and openness, what their colleagues may say. This phase lets students clarify meanings, learn to know and respect opinions, views, emotions and different attitudes. The comments made by the director try to reflect his/her mood and the assessment of the session's training function. Besides referring to internal psycho-affective aspects, comments aim to provide scientific, technical and organizational information about specific contents. 
Since Sociodrama tries to reconcile the knowledge with the day-to-day life and the experience lived, it shows an alternative to a markedly verbal teaching. As a result of its structural and dynamic features, it allows the teaching-learning process to become vivid, active, creative and participative. When using this method, students are encouraged to be co-authors, co-actors and co-responsible for the learning process. They should expose and work their emergent needs, problems and issues, taking into account the motivations, perspectives, characteristics and potential of each individual and of the group as a whole. However, by the rules of tolerance, freedom and respect, participation is not compulsory; nevertheless, attention is paid to everyone.

According to Veiga [18,27], Veiga, Bertão and Franco [28,29] and Veiga and Monteiro [30,31], Sociodrama is particularly important to the training of relationship professionals as social educators, as they need to develop themselves as a person. The personal and social dimensions gain a certain supremacy to these professionals, since they are their main working tool. Thus, it is fundamental that these students have formative spaces that allow them to develop a deeper knowledge and understanding about themselves (e.g., their characteristics, skills, values, weaknesses, conflicts, fantasies, desires, emotions, fears, insecurities, anxieties, prejudices and stories of life) and to train a set of transversal competencies that are essential to their professional practice (e.g., empathic ability, active listening, creativity).

Usually, social education students are faced with different practical situations (e.g., orientation of groups of teenagers/women/elderly in different contexts; meetings with parents/peers/teachers/professionals; and conflict management), which are artificially arranged, although very close to reality. In the protected context of the "as if" (a sociodrama is enacted as if the action is happening in the here and now. Nevertheless, scenes can be from the past, present or future, real or imagined, feared or desired. On the sociodrama stage, time, space and reality are transcended [18,32]), students may, among other things: (a) train new roles; (b) experiment with new patterns of communication, interaction and emotional expression, among other personal and social skills; (c) work through present or future fears, insecurities and difficulties; (d) observe the same situation from other perspectives; (e) test different tools and techniques, without the fear of using them firsthand in reality; (f) learn a working method to be used later in a real intervention; and (g) practice the capacity of supervising and being supervised. These enable them to develop their creativity, spontaneity, flexibility and tolerance, which are essential to social work.

The simulation, for example, of a group orientation, a conflict management or a job interview, allows students to observe, experience and understand how it can be developed. This acquired knowledge would hardly be feasible with the use of mere verbal explanations or descriptions. Experiencing multiple roles and characters-as protagonists or natural auxiliary egos (in dramatic proposals, protagonists interact with auxiliary egos. They may represent figures of many different types: the role of someone in the protagonist's relationships, a fantasized figure, an abstract concept or collective stereotype. There may be professional or natural auxiliary egos, which are chosen by the protagonist from amongst the group members. However, the director may replace them with professional ego(s) in order to perform more delicate techniques [22]) — and many new, unknown or feared "realities", enables students to realize some aspects not previously recognized on themselves, as well as some personal, social and professional weaknesses and skills. This awareness is essential for students in order to initiate a process of personal or collective change. Even when they are not protagonists, the observation of others' role-playing can be more useful than the teachings of the professor, particularly if he/she uses essentially expository methods, enhancers of a more passive, conceptual and non-integrated learning.

As stated in other experiences $[19,33]$ during these classes, students will learn in a deep and integral way and acquire a greater sense of understanding of themselves, of their peers and of the many facets of human and professional realities. In particular, they will: (a) become aware of ethical and moral values, as well as attitudes, beliefs and personal and collective perspectives; (b) develop their emotional and psychological literacy; 
(c) train communication and relational abilities, skills of analysis, improvisation, creativity, emotional management, negotiation and problem solving; (d) become aware of some changes needed, using individual and collective resources; and (e) stimulate autonomy and critical, creative and spontaneous thinking. All these aspects contribute to building up a professional identity as social educators.

In this process of personal knowledge and development, each student plays the creative act of knowing, being simultaneously the subject and the object of knowledge. So, it is essential that they develop a "double vision" [34], that is, to make a conscious effort to, first of all, look upon themselves and have the ability to question who each individual is, and second, to look at their relationship with the other(s).

The progressive trust and group cohesion provide opportunities to: (a) develop a more effective and complete communication between everyone, thereby enhancing a deeper understanding; (b) break crystallized and/or stigmatizing reputations of specific elements, thereby leveraging new and deeper relationships; (c) learn to work in groups and mobilize individual and collective resources and skills; (d) (re)equate visions and behaviors, expanding the repertoire of alternative interaction and preventing the emergence of conflict situations, (e) break stereotypical behaviors; and (f) develop critical and original thinking, opening the possibility of new learning based on the binomial spontaneity-creativity [22].

\section{Developing Transversal Competencies with the Body in Action}

There is a multiplicity of transversal competencies that can be developed by the Sociodrama method, such as empathy, active listening, tolerance, participatory decisionmaking, collaborative strategies, teamwork, commitment, assertiveness, stress and time management, critical thinking, confidentiality, leadership and team management, social responsibility, emotional management, conflict resolution, flexibility and decision making.

Among the most significant competencies, one can emphasize active listening, acceptance, empathic ability, curiosity, creativity, confidence and reflective posture, which are particularly important for social educators. All of these are worked and trained in the different phases of a session of Sociodrama, as shown below.

Active listening - to latent or expressed contents—is essential to the students' understanding of what others (do not) say, feel and act accordingly. It demonstrates a genuine but not invasive curiosity regarding the life stories of others and a respect for their conceptions, feelings and experiences. As stated by Freire [35], curiosity is what drives the professional, makes him/her restless and sets him/her on the path of searching. In this way, the stimulation of curiosity, which drives students to seek, to think, to question and mandatorily to listen, is another fundamental competence for the relationship professional developed in the sociodramatic space and in all the phases.

As defended by Rogers [36], other basic competences of the professional, as a person, are unconditional acceptance and empathy. Since the beginning, students are sensitized to accept their peers, respecting their diversity and differences. They are equally enlightened to be emotionally available to assist them, and intentionally free of pressure and value judgments. This acceptance of others as they really are-with their strengths and weaknesses, focusing on the positive aspects that can facilitate and enhance the process of change-is essential in future professional practice. The acceptance of oneself, with qualities and weaknesses, is also stimulated and enhanced. Particular techniques can be used to stimulate this process, such as an adaptation of the mask technique [37] (Figure 1).

The students from all images have authorized its publication.

Empathy is developed mainly in the dramatization phase. In some scenes, the protagonist is invited to interact with a complementary character (e.g., a bullied teenager, a colleague or a teacher) and to exchange roles with him/her, through the role reversal technique. Some elements of the group can also assume a character as natural auxiliary egos (e.g., children/teenagers of a problematic class) (Figure 2). 


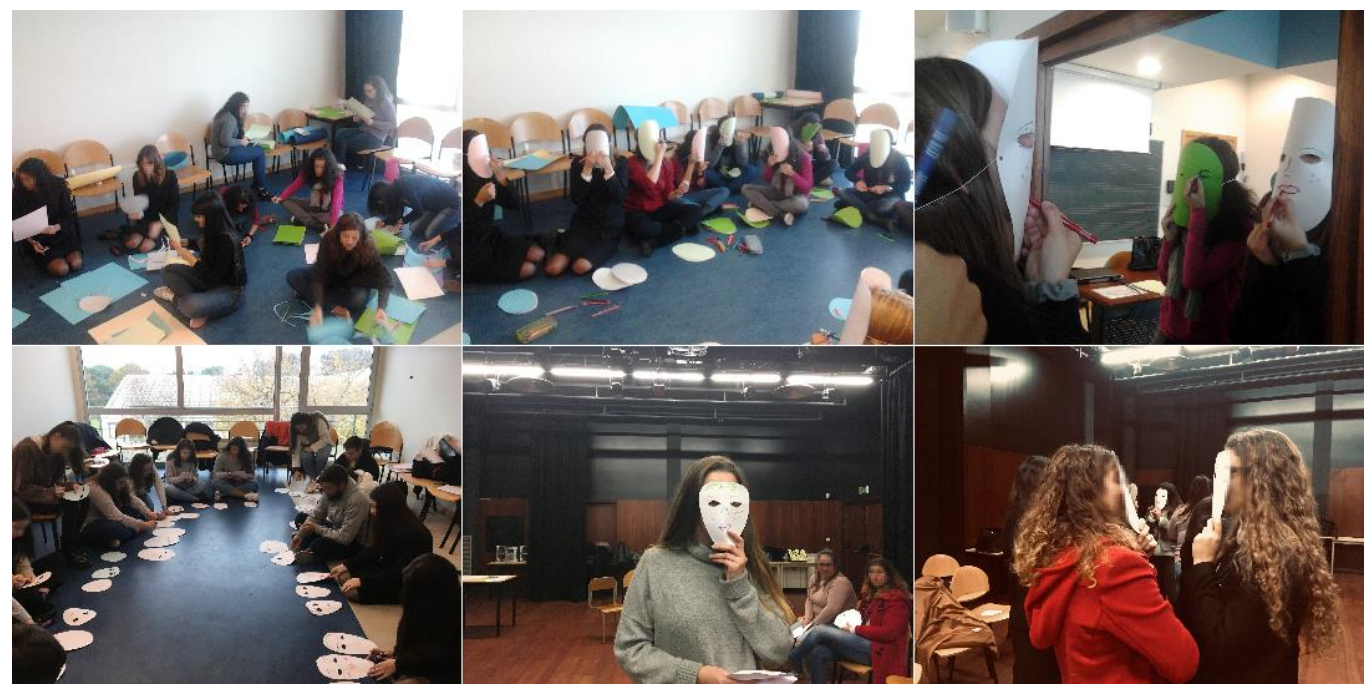

Figure 1. Knowledge and acceptance of self and others: mask technique activity.
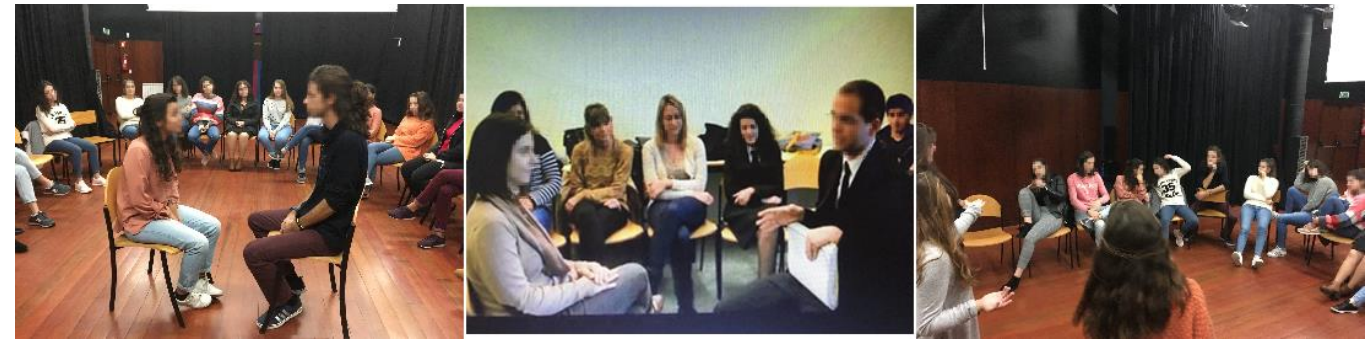

Figure 2. Empathy: role reversal and role-playing techniques.

Thus, protagonist and natural auxiliary egos are challenged to know and understand the internal and external world of the (complementary) character as if it was their own world, inhabited by thoughts and positive and negative feelings, and often unknown by the person itself. As stated by Rogers [36], this should be done without confusing and merging the worlds of one individual and another because the aim is to help the person to become aware of oneself and give meaning to what they lived and felt. It is therefore essential that students understand the importance of maintaining the optimum distance-proximity in the interactional reality, which is needed for the autonomy and freedom of the participants to be themselves in their own processes of learning and development.

Secrecy and confidentiality are discussed, understood and trained in these classes, since everything that happens in the group must stay in the group. Through dialogues and dramatic experiences, students realize the importance of confidentiality of information gathered during the professional practice, except in rare cases in which the professional duties require the disclosure of information. Secrecy is encouraged from the first session, being one of the rules of this space. Sometimes confidentiality is the focus of one or several sessions and can be worked through different techniques, such as sculptures, soliloquies and role reversals (Figure 3 ).

Creativity is specifically worked on during the dramatization phase. In the assembled scenes and through mobilized techniques, according to the emergent themes and the therapeutic hypotheses, the professor-director and student-protagonists enter and engage in a creative dynamic, rich in symbols and meanings. Sculpture (e.g., of the professional profile and values, of the real and the desired group, and of feelings) is one of the techniques that better allows the development of this competence (Figure 4). 


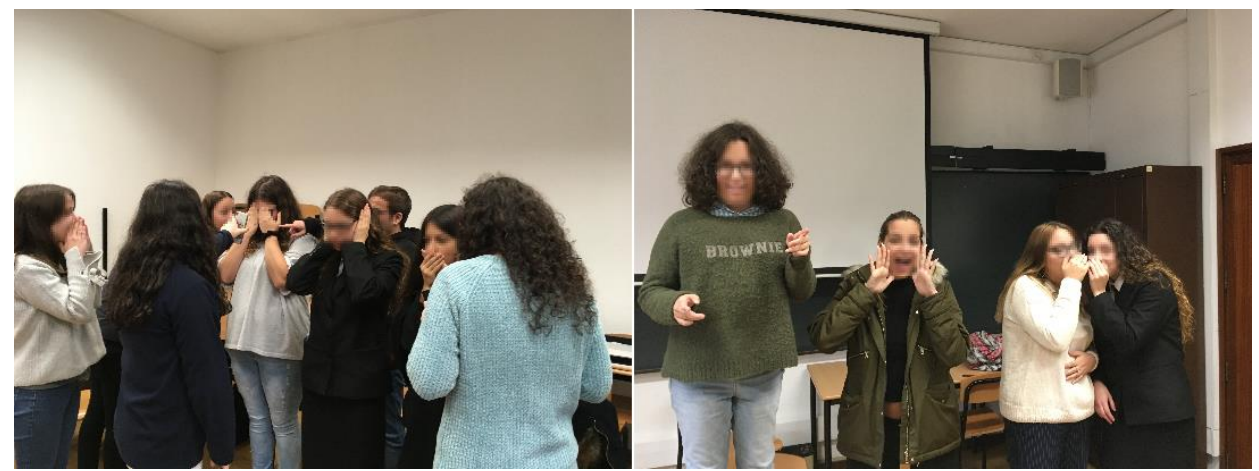

Figure 3. Confidentiality: human sculptures.

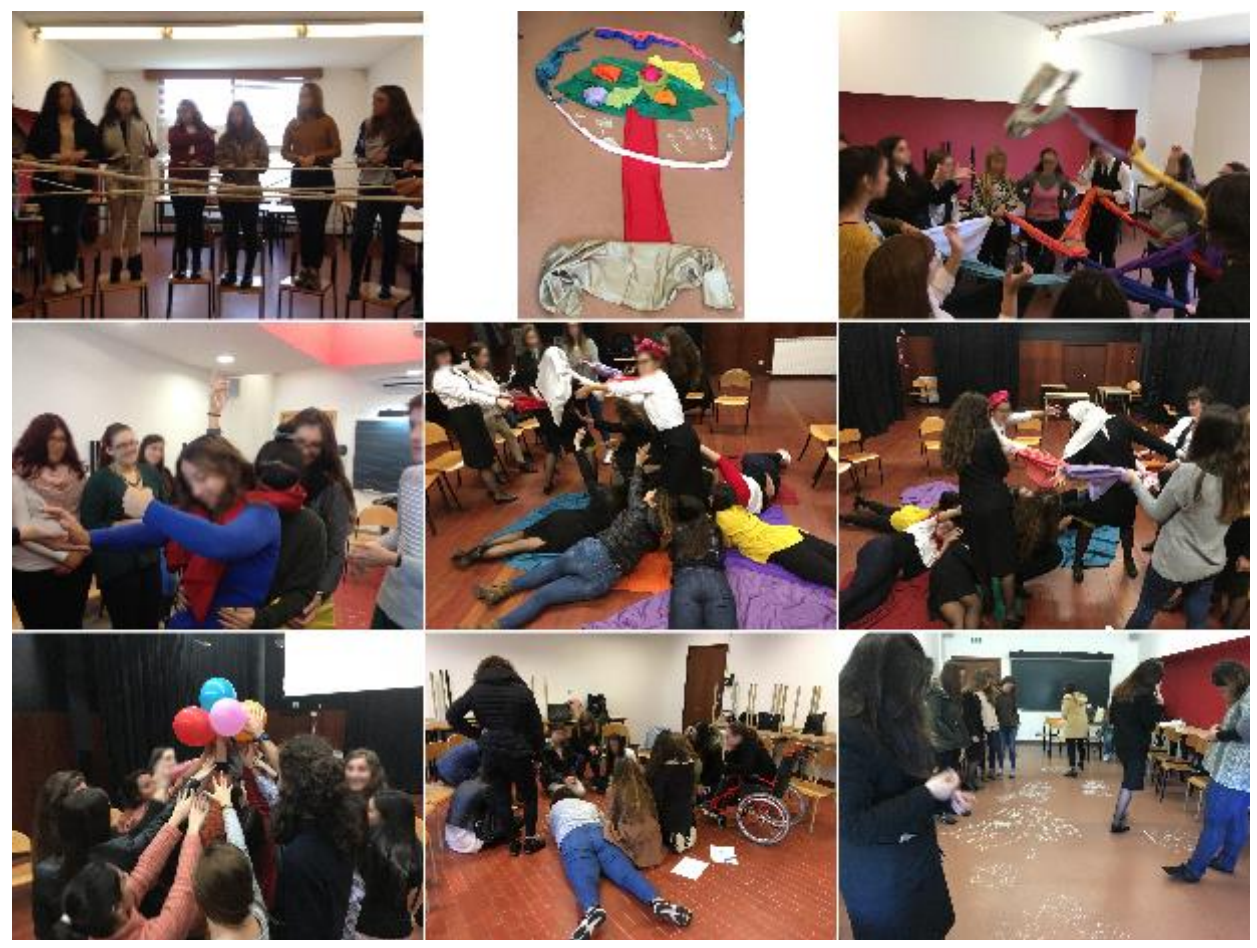

Figure 4. Creativity: sculptures and graphic representations.

The questioning and the gradual assumption of a reflective posture and criticism about oneself, about others and about the multiple psychosocial realities portrayed, occur when in action. On the stage, students question themselves about who they are and what they do in the encounter with others, taking into account the reality and circumstances surrounding them. This attitude of permanent vigilance allows them to: gain awareness about their conceptions, values and emotions; and assess their postures, attitudes and behavior. During this process, they also perceive and mobilize resources (endogenous and exogenous) in favor of a more comprehensive and harmonious development. Furthermore, as they are co-responsible for the training, they also assume a critical and reflective attitude with their peers. Particularly during the comments phase, they share and give feedback to others in order to enable each other to face and to be open to new perspectives, behaviors and emotions.

Finally, I would like to emphasize the role of the professor-director, who is in charge of the whole process. By using the Sociodrama method, he/she is able to teach in a more creative, lively and innovative way. He/she becomes a facilitator, a mentor, being continuously aware of the group dynamics, the students' needs and skills, as well as the training goals. Sociodramatic practice requires a humanistic attitude. By assuming a posture of empathy, genuineness and acceptance, he/she: (a) adopts the students' reference 
frames so that the desire to know, learn and change is perceived by them as real and necessary; (b) believes that students possess the capacities and resources essential to their learning process and development; (c) fosters hope as well as other therapeutic factors present in groups [38]; (d) understands each and every person in his/her uniqueness; (e) guides and provides scientific and technical contents for their growing professional identity; and (f) enhances their development as a whole. While performing, he must be flexible, creative and spontaneous (Figure 5).
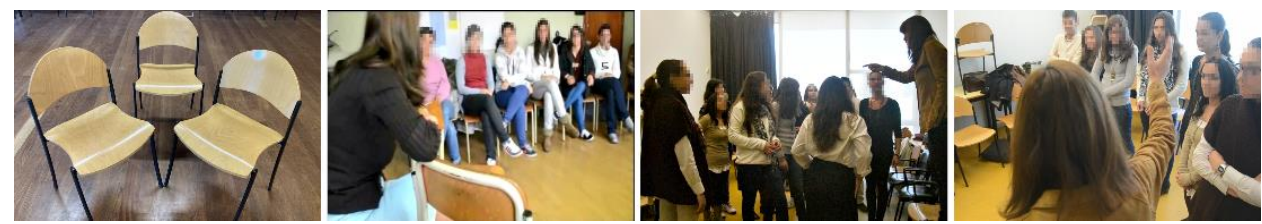

Figure 5. Professor-Director Role.

As these Curricular Units are compulsory, the final classification is based on participation throughout the year and on the realization of a logbook, which consists of a description of each class and an individual reflection that integrates the experiences and learning theoretically framed.

\section{The Sociodramatic Experience in Times of Pandemic}

During the pandemic, few face-to-face classes were held. Online distance education forced the whole teaching-learning process to be rethought and readjusted. In the case of the Curricular Units focused upon in this paper, which engage Sociodrama as a teachinglearning method, some changes took place, e.g., the context became virtual. When learning during the pandemic was face-to-face, the distance and the use of masks conditioned the work as well as the relational dynamics that had been developed before. Some changes also became permanent (e.g., phases, instruments, the three contexts and the guiding principles). While maintaining a space of freedom, the students were able to bring their questions and concerns, as persons, citizens, students in training and future social educators. They had never had such overwhelming demands as in these times. Not only did they have to continue their training to respond to a demanding labor market, which now brought new challenges to the intervention of professionals and to social intervention itself, but they also had to, in their life contexts, assume themselves as active and intervening persons and citizens. This was a period full of difficulties, but also of many opportunities. The sharing of ideas flowed naturally during the warm-up phase, and during the roleplaying phase, a multiplicity of scenes were staged on the problematic/thematic areas approached, although some techniques were used less or had to be reinvented. As examples of the themes dealt with, we may refer to the fears and anxieties felt (in relation to their own health and that of their families and/or of the general population; their academic training; or their professional future), arising from a scenario of uncertainty; emotional management; the (re)organization and management of times and tasks; the redefinition of various relationships (among peers, with the family, with partners); civic participation in times of elections; and the intervention of welfare workers with different populations and in different contexts, either in person or at distance. The dramatization phase was particularly challenging for the students and the professor-director, as it was expected to be as experiential as possible. Parallel rooms, a blank sheet or objects and materials they had at home were often used. The personal cameras were turned on and/or off, giving focus to the elements they were protagonizing. The group was often felt to be a source of support and containment of anxieties, fears and concerns. With each other, they could see how they could (better) live that moment, how they could manage emotions, how they could be present people and social educators, even at a distance. Among the transversal skills trained, empathic listening, emotional management and social responsibility were undoubtedly among the most developed in this space. Week after week, students discussed 
and analyzed, together, situations from their personal lives, academic challenges and social reality in general, and considered themselves as active individuals in the resolution of some of them, either as citizens or as social educators. Most of the students were very assiduous in these classes, which they considered a privileged space for listening, sharing, reflection and complicity.

\section{The Students' Voices}

As participants, students' voices are very important, therefore, their testimony will be presented. The following text was written by a group of students who accepted this challenge and gathered to analyze sociodramatic space and its benefits to their personal, social and professional development. Students were aware that their (heartfelt) testimony would be included in the professor's scientific article.

"It was in the safe space of the Sociodrama sessions that we met and where we were free to play and experience new and old roles. It was principally in terms of values, self-knowledge and relationship with each other that these roles were experienced, and the limits of human relationships tested. There were confrontations among us, but, above all, there was personal confrontation, in which each individual became aware of their own characteristics, ways of acting, being and feeling, which we were not always fully aware of and that often deeply conditioned developed relationships.

Sociodrama sessions fulfilled their role as an active methodology. As educational and therapeutic practice, during these sessions we discovered challenges and explored meanings for social education and for the educator; we outlined projects and intervention strategies, which helped us to solve our everyday problems at school, whether as students, members of the academic community or as future social educators.

Throughout this path of discovery, we realized how we can and want to be at school, and in our professional and personal life. We recreate situations, we dramatize pieces of ourselves, pieces of each other. It was there and then that empathy turned from an abstract theoretical content into a practical everyday life value.

We discovered Sociodrama is essentially a methodology of transformation, promoting self-reflection, self-knowledge and better human relationships.

In an atmosphere of respect and tolerance, we tried new ways of organization, dialogue and negotiation. We walked the path of listening until listening was no longer a commitment to pleasure, discovery and knowledge. Through listening, instead of interpretations, we learn to put ourselves in the other one's shoes.

As we deepened our inner-knowledge process, we developed the capacity to accept ourselves and to be more authentic and humbler in our relationships.

Sociodrama sessions were often a battle: a personal battle against rigidity and for creativity, spontaneity and congruence. Through diverse techniques-such as role-reversal, soliloquy, doubling, role-playing or sculptures-it has become possible to experience shady and even unknown sides of ourselves, as a person and as a group. In a safe space, we could share and validate our perspectives and experiences. Attention and comprehension were tested, and many preconceptions and stereotypes were deconstructed. We could write ourselves on a sheet of paper, erase ourselves, redesign, color, scratch, rethink, redefine, be a blank sheet, be a filled sheet ... At the end of the sessions, we felt stronger, better prepared, more mature to face life!

All this was possible as part of an academic path. And it should be like that, since we believe higher education, particularly the degree for social educators, should never be disconnected from life. As it must have transformative effects on 
students, it cannot simply be an accumulation of theories, facts, data and patterns.

It must take into consideration all colors of life."

Even though most of the students recognize and value the use of Sociodrama in the two years of training, some constraints/resistances will arise as: (a) its praxis requires involvement, and social and emotional commitment from the students to the group, as well as autonomy and a responsibility for what occurs throughout the sociodramatic sessions; and (b) the sessions take place in a compulsory curriculum context. Thus, some students do not appreciate these classes, do not participate actively in them and do not act accordingly with the common good, influencing relational and formative dynamics, as well as growth, both of the individual and the group [18,29].

\section{Conclusions}

In Higher Education, students must acquire rigorous technical-scientific knowledge specific to their degree and develop a range of transversal competencies essential for a successful academic and professional career. There are many experiences and programs, in different realities, that develop these competencies [10-15]. In the Social Education degree of the Higher Education School of the Polytechnic Institute of Porto, these competencies are mainly trained and developed within two Curricular Units, where Sociodrama is used as an active, creative and innovative educational methodology that relies on the active participation of students to construct knowledge, on their integral development and on their building up of a professional, reflexive and interventive attitude.

In an interactional dance (with colleagues, the professor-director and the auxiliary ego), they get to know each other, develop and transform themselves. Throughout the three phases of a session, and during the sociodramatic process, students may: (a) share doubts, anxieties and concerns, realizing that their personal drama is often shared by others; (b) perceive multiple perspectives and conceptions, validating or reformulating ways of thinking, feeling and acting; (c) become aware of personal and professional values, and the necessity of its convergence; (d) identify personal and professional characteristics, skills and weaknesses; (e) consider the need for internal and/or external changes; (f) broaden and/or deepen their relationships; (g) train a multiplicity of transversal competencies; and (h) widen their knowledge about the fundaments, intervention scopes and strategies of the future profession.

Although the experience narrated is part of the social education training, I believe that a similar experience would be very relevant in other courses and degrees, particularly in those whose professionals work with individuals and/or groups. The training and development of a set of transversal competencies-namely leadership, empathetic listening, emotional management, conflict resolution and decision making-would significantly empower these professionals to perform their respective roles spontaneously and creatively.

Curricular Units of this nature, whether compulsory or optional, are very important and useful in preparing students as professionals and responsible citizens, aware of their active, critical, creative, innovative and transforming role in the society/world they live in [39].

Funding: This work is funded by National Funds through the FCT-Fundação para a Ciência e a Tecnologia, I.P., under the scope of the project UIDB/05198/2020 (Centre for Research and Innovation in Education, inED).

Institutional Review Board Statement: Ethical procedures were followed.

Informed Consent Statement: Participants in the activities described in this article were informed about the objectives of their participation. Their authorization was requested to collect information on the activities in which they participated, with all participants consenting.

Conflicts of Interest: The author declares that she has no conflict of interest. 


\section{References}

1. Almeida, L.; Vasconcelos, R. Ensino superior em Portugal: Décadas de profundas exigências e transformações [Higher education in Portugal: Decades of profound demands and transformations]. Innov. Educ. 2008, 18, 23-24.

2. Almeida, L.; Marinho-Araujo, C.; Amaral, A.; Dias, D. Democratização do acesso e do sucesso no ensino superior: Uma reflexão a partir das realidades de Portugal e do Brasil [Democratization of access and success in higher education: A reflection from the realities of Portugal and Brazil]. Aval. Campinas 2012, 17, 899-920. [CrossRef]

3. Cerdeira, L.; Cabrito, B. Democratização e acessibilidade no ensino superior em Portugal: Mudanças recentes [Democratization and accessibility in higher education in Portugal: Recent changes]. Acta Sci. Educ. 2018, 40, e40632. [CrossRef]

4. Rosário, P.; Mourão, R.; Núnez, J.; González-Pienda, J.; Soiana, P.; Valle, A. Eficacia de un programa instruccional para la mejora de procesos y estrategias de aprendizaje en la enseñanza superior [Efficacy of an instructional program for the improvement of processes and learning strategies in higher education]. Psicothema 2006, 1, 422-427.

5. Almeida, L. Transição, adaptação académica e êxito escolar no ensino superior [Transition, academic adaptation and academic success in higher education]. Galego-Port. Psicol. Educ. 2007, 14, 203-215.

6. Wood, M.; Su, F. What makes an excellent lecturer? Academics' perspectives on the discourse of 'teaching excellence' in higher education. Teach. High. Educ. 2017, 22, 451-466. [CrossRef]

7. Beerkens, M. Evidence-based policy and higher education quality assurance: Progress, pitfalls and promise. Eur. J. High. Educ. 2018, 8, 272-287. [CrossRef]

8. Lacerda, F.; Santos, L. Integralidade na formação do ensino superior: Metodologias ativas de aprendizagem [Integrality in higher education training: Active learning methodologies]. Aval. Camp. 2018, 23, 611-627. [CrossRef]

9. Silva, B.; Neto, V.; Gritti, N. Soft skills: Rumo ao sucesso no mundo profissional [Soft Skills: Toward success in a professional world]. Interface Tecnol. 2020, 17, 829-842. [CrossRef]

10. Jardim, J.; Pereira, A.; Vagos, P.; Direito, I.; Galinha, S. The Soft Skills Inventory: Developmental procedures and psychometric analysis. Psychol. Rep. 2020, 125, 620-648. [CrossRef]

11. Santos Silva, R.; Nascimento, I. Ensino superior e desenvolvimento de competências transversais em futuros economistas e gestores [Higher Education and soft skills' development for future managers and economists]. Bras. Orient. Prof. 2014, 15, $225-236$.

12. Skowron, A.; Dymek, J.; Gołda, A.; Polak, W. Are we ready to implement competence-based teaching in pharmacy education in Poland? Pharmacy 2017, 5, 25. [CrossRef] [PubMed]

13. Tsankov, N. Development of transversal competences in school education (a didactic interpretation). Int. J. Cogn. Res. Sci. Eng. Edu. 2017, 5, 129-144. [CrossRef]

14. Sá, M.J.; Serpa, S. Transversal competences: Their importance and learning processes by higher education students. Edu. Sci. 2018, 8, 126. [CrossRef]

15. Sá, M.J.; Serpa, S. Higher Education in Times of Change, 1st ed.; Services for Science and Education: Stockport, UK, 2020.

16. Romans, M. Funciones y competencias del educador social [Functions and competences of the social educator]. In De Profesión: Educador(a) Social [The Profession: Social Educator], 1st ed.; Romans, M., Petrus, A., Trilla, J., Eds.; Paidos: Barcelona, Spain, 2000.

17. Gonçalves, C. Desenvolvimento vocacional e promoção de competências [Vocational development and skills promotion]. In Construção de Competências Pessoais e Profissionais Para o Trabalho: Actas do II Encontro Internacional de Formação Norte de Portugal/Galiza [Building Personal and Professional Skills for Work: Proceedings of the II International Training Meeting North of Portugal/Galicia], 1st ed.; II Encontro Internacional de Formação norte de Portugal/Galiza: Porto, Portugal, 2001; pp. 69-78.

18. Veiga, S. Palcos de Conhecimento, Espaços de Transformação. Contributos da Metodologia Sociodramática Para a Formação dos Educadores Sociais [Stages of Knowledge, Spaces of Change. On Sociodrama as a Methodology for Training Social Educators]. PhD Thesis, University of Évora, Évora, Portugal, 2009.

19. Blatner, A. Enacting the new academy: Sociodrama as a powerful tool in higher education. ReVision 2006, 28, 30-35. [CrossRef]

20. Wittinger, T. Discovering Sociodrama. In Sociodrama in a Changing World, 1st ed.; Wiener, R., Adderley, D., Kirk, K., Eds.; Lulu.com: Morrisville, NC, USA, 2011; pp. 313-321.

21. Álvarez Valcarce, P. Key Elements in a Sociodramatic Aproach to Groupwork. In Sociodrama in a Changing World, 1st ed.; Wiener, R., Adderley, D., Kirk, K., Eds.; Lulu: Morrisville, NC, USA, 2011; pp. 91-111.

22. Moreno, J. Psychodrama, 1st ed.; Beacon House Press: Beacon, NY, USA, 1946; Volume I.

23. Cieplinski, K.M.; Karkut-Rzondtkowska, J. Significant events during a psychodrama and action methods based experiential group training for psychology students. Psychodrama Soziom 2019, 18, 153-165. [CrossRef]

24. Cruz, A.; Sales, C.; Alves, P.; Moita, G. The core techniques of morenian psychodrama: A systematic review of literature. Front. Psychol. 2018, 9, 1263. [CrossRef]

25. Soeiro, A. The Audience Instinct. In the Society of the Spectacle, 1st ed.; Círculo de Giz: Brasília, Brazil, 2003.

26. Veiga, S. (Re)nacer en el papel de yo-auxiliar, (re) construer el rol profesional [(Re)born in the role of auxiliary ego, (re)construct the professional role]. In Proceedings of the Actas de la XXVIII Reunión Nacional de la Asociación Española de Psicodrama [XXVIII National Meeting of the Spanish Psychodrama Association], Sevilla, Spain, 22-24 November 2013; Baena, M., Fernández, M.D., Coppel Hidalgo, A., Eds.; Punto Rojo Libros: Sevilla, Spain, 2013; pp. 356-369.

27. Veiga, S. Quando o processo de Ensino-aprendizagem é mediatizado pelo palco psico/sociodramático .... [When the teachinglearning process is mediated by the psycho/sociodramatic stage ... ]. Revista Soc. Port. Psicodrama 2014, 7, 99-114. 
28. Veiga, S.; Bertão, A.; Franco, V. A metodologia sociodramática na formação pessoal de profissionais da relação [The sociodramatic methodology in the personal training of relationship professionals]. In Diálogos Dentro da Psicologia: Contributos da Investigação Luso-Brasileira em Psicologia Social, Clínica e Educacional [Dialogues Within Psychology: Contributions of Portuguese-Brazilian Research in Social, Clinical and Educational Psychologyl, 1st ed.; Aloendro: Évora, Portugal, 2011; pp. 16-32.

29. Veiga, S.; Bertão, A.; Franco, V. Sociodrama in the training of social educators. An exploratory research. J. Psychodrama Sociom. Group Psychother. 2015, 63, 47-64. [CrossRef]

30. Veiga, S.; Monteiro, H. Formação valorativa dos educadores sociais. Princípios, metodologias e construtos teórico-conceptuais [Axiological training of social educators. Principles, methodologies and theoretical-conceptual constructs]. Sensos-e $2013,4269$.

31. Veiga, S.; Monteiro, H. Axiological approach in the training os students of social education degree. Edu. Real. Porto Alegre 2017, $42,579-604$.

32. Giacomucci, S. Social Work, Sociometry, and Psychodrama. Psychodrama in Counselling, Coaching and Education, 1st ed.; Springer: Singapore, 2021.

33. Maya, J.; Jesús, M. Teaching-learning processes: Application of educational psychodrama in the university setting. Int. J. Environ. Res. Public Health 2020, 17, 3922. [CrossRef] [PubMed]

34. Capul, M.; Lemay, M. De L'éducation Speécialisée [Specialized Education], 12th ed.; ERES: Toulouse, France, 2019.

35. Freire, P. Pedagogia da Autonomia: Saberes Necessários à Pratica Educativa [Pedagogy of Autonomy: Necessary Knowledge for Educational Practice]; Paz e Terra: São Paulo, Brazil, 1996.

36. Rogers, C. On Becoming a Person: A Therapist's View of Psychotherapy, 7th ed.; Mariner Books: Boston, MA, USA, 1995.

37. Rojas-Bermúdez, J.; Moyano, G. Enmascararse/Desenmascararse. Las máscaras en sicodrama [Mask/Unmask. The masks in psychodrama]. In Actualizaciones en Sicodrama [Actualizations in Psychodrama], 1st ed.; Rojas-Bermúdez, J., Ed.; Edicions Espiral Maior: Galicia, Spain, 2012; pp. 113-136.

38. Yalom, I.; Leszcz, M. The Theory and Practice of Group Psychotherapy, 6th ed.; Basic Books: New York, NY, USA, 2020.

39. Goergen, P. Educação Superior. Entre formação e performance [Higher Education. Between personal development and performance]. Avaliação 2008, 13, 809-815. [CrossRef] 